\title{
Non-invasive spectral detection of the beneficial effects of Bradyrhizobium spp. and plant growth-promoting rhizobacteria under different levels of nitrogen application on the biomass, nitrogen status, and yield of peanut cultivars
}

\author{
Salah Elsayed ${ }^{1 \star}$, Mohamed Elhoweity ${ }^{1}$, Salah El-Hendawy ${ }^{2,4}$, Urs Schmidhalter ${ }^{3}$ \\ 1. University of Sadat City - Environmental Studies and Research Institute - Department of Evaluation and Natural \\ Resources - Sadat, Egypt. \\ 2. King Saud University - College of Food and Agriculture Sciences - Department of Plant Production - Riyadh, Saudi Arabia. \\ 3. Technische Universität München - Department of Plant Sciences - Freising, Germany. \\ 4. Suez Canal University - Faculty of Agriculture - Department of Agronomy - Ismailia, Egypt.
}

\begin{abstract}
High-throughput phenotyping using spectral reflectance measurements offers the potential to provide more information for making better-informed management decisions at the crop canopy level in real time. The aim of this study was to investigate the suitability of hyperspectral reflectance measurements of the crop canopy for the assessment of biomass, nitrogen concentration, nitrogen uptake, relative chlorophyll contents, and yield in 2 peanut cultivars, Giza 5 and Giza 6. Peanuts were grown under field conditions and subjected to 3 doses of nitrogen fertilizer with or without the application of 2 bio-fertilizers, Bradyrhizobium spp. or plant growth-promoting rhizobacteria. Simple linear regression of normalized difference spectral indices and partial least square regression (PLSR) were employed to develop predictive models to estimate the measured parameters. The tested spectral
\end{abstract}

reflectance indices were significantly related to all measured parameters with $\mathrm{R}^{2}$ of up to 0.89 . The spectral reflectance index values differed at the same level of nitrogen fertilizer, as well as among the 3 levels of nitrogen fertilizer application for inoculation with Bradyrhizobium and co-inoculation with Bradyrhizobium and plant growth-promoting rhizobacteria. The calibration models of PLSR data analysis further improved the results, with $\mathrm{R}^{2}$ values reaching 0.95 . The overall results of this study indicate that hyperspectral reflectance measurements monitoring peanut plants enable rapid and non-destructive assessment of biomass, nitrogen status, and yield parameters of peanut cultivars subjected to various agronomic treatments.

Key words: biofertilizer, phenomics, phenotyping, precision agriculture, spectral reflectance. 


\section{INTRODUCTION}

Nitrogen is an important element for proper plant development and reproduction because it is a component of chlorophyll, amino acids, proteins, and enzymes. An efficient nitrogen supply is required for plant metabolism, and the addition of nitrogen will increase crop photosynthesis and final yields (Erisman et al. 2010). There are different interesting crop canopy parameters, such as the nitrogen concentration, nitrogen uptake, and aboveground biomass, which can be used as diagnostic indicators of nitrogen requirements for crops. In order to match nitrogen requirements as closely as possible, the spatial and temporal variations of these indicators on the field scale must be determined (Schmidhalter et al. 2003). The application of nitrogen is known to have direct positive impact on the final yield of all crops. Increasing the level of nitrogen fertilizer increased the pod yield, pod weight, seed yield, and seed weight of peanut plants (Barik et al. 1998). Nitrogen fertilizer is one of the most critical inputs in plant production. However, all forms of mineral nitrogen fertilizers are subjected to possible losses, especially when applied at high doses. The risks of nitrogen loss depend on the site and climate conditions, as well as the nitrogen form. The cost of nitrogen fertilizer represents the largest share of the total production costs of agricultural crops, accounting from 20 to $30 \%$ of the variable production cost in cereals crops. Therefore, the application of Bradyrhizobium spp. (Br) and plant growth-promoting rhizobacteria (PGPR) in legume crop production has been suggested as a suitable alternative strategy to bypass the risk of chemical fertilizers (Badawi et al. 2011). Enhancement of nodulation and biological nitrogen fixation of legumes by co-inoculation with PGPR microorganisms is becoming a practical way to improve nitrogen use efficiency in sustainable agricultural production systems (Bai et al. 2002). PGPR can promote legume nodulation and nitrogen fixation by producing flavonoid-like compounds and/or stimulating the host plant to produce more flavonoid signal molecules (Bai et al. 2002).

For economic and ecological reasons, spatially-targeted and temporally-optimized nitrogen fertilizer application has become a pressing issue in the field of crop production. Generally, current fertilizer management depends on soil analysis, but these practices frequently disregard locally variable nitrogen demand (Mistele and Schmidhalter 2008). Plant analysis is important to control nitrogen status, but destructive methods are tedious and timeconsuming. Similarly, for detecting the final yield of crops in a field, numerous observations are required to characterize that field.

Plant phenotyping is currently considered one of the key-factors in agricultural research to overcome such observational and time constraints and is predicted to play a vital role in ensuring yield stability and future improvements in crop yield and quality (Furbank and Tester 2011). Spectral approaches have been proposed to be efficient, high-throughput, and cost-effective, and allow simultaneous phenotyping of several important agronomic traits in field trials (Walter et al. 2012; Winterhalter et al. 2012). High-throughput precision agriculture and phenotyping using spectral reflectance measurements have further potential to provide more information to facilitate better-informed management decisions at the crop canopy scale in real time (Mistele and Schmidhalter 2010; Elsayed et al. 2011; Rischbeck et al. 2014; El-Hendawy et al. 2015). Proximal remote sensing systems for phenotyping on the field scale can be based on passive reflectance sensing. Passive sensor systems depend on sunlight as a source of light, which enables hyperspectral information to be obtained in the visible and near-infrared range (Erdle et al. 2011; Elsayed et al. 2015a).

Despite the potential benefits of hyperspectral assessments, at present, there is little information available regarding the efficacy of hyperspectral assessments in characterizing biomass, nitrogen status, and yield parameters of peanut cultivars inoculated with different sources of bio-fertilizers and subjected to different levels of mineral nitrogen fertilizer application. The use of high-throughput remote or proximal sensing to assess such parameters for peanuts has rarely been reported in literature. For example, the closest relationships were obtained for the spectral index $\left(\mathrm{R}_{610}-\mathrm{R}_{424}\right) /\left(\mathrm{R}_{610}+\mathrm{R}_{424}\right)$ with the pod yield of 2 peanut cultivars ( $R^{2}$ up to 0.70 , significant at $p \leq 0.001$ ) at 3 growth stages under 3 levels of mineral nitrogen fertilizer application (Elsayed et al. 2015a). The hyperspectral analysis of growing peanut leaves delivered significant correlations (up to $\mathrm{r}=0.73^{* *} ; \mathrm{p}=0.006$ ) between pod maturity and crop canopy reflectance using the normalized difference vegetation index (NDVI) derived from high-resolution multispectral satellite imagery (Robson et al. 2004). For reflectance measurements of 
growing leaves with field spectroscopy, the explanation of variance was greater than $90 \%$ using partial least square regression (PLSR) analysis with wavelengths of 640; 656; 747; 964 and 1,124 $\mathrm{nm}$.

This study therefore aims to confer novel information by investigating changes in spectral indices under different levels of mineral nitrogen fertilizer application in combination with 2 sources of bio-fertilizers, Bradyrhizobium and plant growth-promoting rhizobacteria.

There have been several previous studies assessing biomass, nitrogen status, and grain yield of cereals related to mineral nitrogen fertilizer application alone. For example, the spectral index $\left(\mathrm{R}_{760} / \mathrm{R}_{730}\right)$ was related to the grain yield of wheat cultivars under different levels of nitrogen fertilizer application (Erdle et al. 2013). The red edge inflection point (REIP) was closely related to the nitrogen uptake of wheat from tillering to flowering (Mistele and Schmidhalter 2008). Fu et al. (2014) reported that the NDVI and the soil adjusted vegetation index (SAVI) were related to the biomass of wheat.

An alternative approach is to conduct a PLSR analysis of hyperspectral reflectance data. This approach is a chemometric technique that creates orthogonal latent variables across the input variables (single wavebands) and relates them to the target variables by generalizing and combining the methods of principal component analysis (PCA) and multiple regressions (Sharabian et al. 2014). Therefore, it could be used to predict a set of dependent variables from a large set of independent ones (i.e. predictors) that may be correlated. In PLSR, the orthogonal components, unaffected by collinearity, are derived from all variables (Weber et al. 2012). PLSR improved the assessment of pod yield of peanut cultivars (Elsayed et al. 2015a), biomass of winter wheat (Fu et al. 2014; Li et al. 2014), and the N status in wheat and maize based on ground-based spectral data (Bonfil et al. 2005).

The purpose of this work was: (i) to study the effect of the interaction between 3 levels of nitrogen fertilizer application with and without Br and PGPR on biomass fresh and dry weight, nitrogen concentration, nitrogen uptake, SPAD value, pod and seed yield, and the shelling percentage of 2 peanut cultivars at 2 growth stages; (ii) to assess whether spectral indices can reflect changes in the abovementioned variables; (iii) to compare the performance of spectral reflectance indices and PLSR to assess the abovementioned plant traits of peanut cultivars at 2 growth stages.

\section{MATERIAL AND METHODS Field experiments and design}

Field experiments were conducted at the Research Station of the University of Sadat City, Egypt (lat $30^{\circ} 2^{\prime} 41.185^{\prime \prime} \mathrm{N}$; long $31^{\circ} 14^{\prime} 8.1625^{\prime \prime} \mathrm{E}$ ), which is characterized by a semi-arid climate with moderate cold winters and warm summers. The experimental treatments consisted of 2 peanut cultivars (Giza 5 and Giza 6) and 3 nitrogen fertilizer rates $(\mathrm{N} 1=24$; $\mathrm{N} 2=48$ and N3 $=96 \mathrm{~kg} \cdot \mathrm{ha}^{-1}$ ) combined with or without $\mathrm{Br}$ (strain USDA 3456) and PGPR. The field experiments were designed as a split-plot design with 3 replicates. The 2 cultivars were assigned to the main plots, while the various fertilizer treatments were distributed randomly in sub-plots.

The PGPR contained Azospirillum brasilense (NO 40) and Serratia marcescens (EG 10). The nitrogen fertilizer was added in 2 equal doses. The first dose was added at the sowing date and the second was applied 21 days after sowing in the form of ammonium nitrate $\left(\mathrm{NH}_{4} \mathrm{NO}_{3}\right.$ $33.5 \%)$. All treatments received the recommended dose of superphosphate $\left(15.5 \% \mathrm{P}_{2} \mathrm{O}_{5}\right)$ at a rate of $476 \mathrm{~kg} \cdot \mathrm{ha}^{-1}$ and potassium sulfate $\left(48 \% \mathrm{~K}_{2} \mathrm{O}\right)$ at a rate of $119 \mathrm{~kg} \cdot \mathrm{ha}^{-1}$. Drip irrigation was used. The peanut cultivars were sown on 15 May 2013 in sandy loam soil that contains $72.8 \%$ sand, $19.3 \%$ silt, and $7.9 \%$ clay. The soil is characterized by an electrical conductivity of $1.82 \mathrm{dS} \cdot \mathrm{m}^{-1}$, organic matter content of $0.36 \%$, and calcium carbonate content of $5 \%$. The plots consisted of 3 rows spaced $60 \mathrm{~cm}$ apart with a length of $3 \mathrm{~m}$. Herbicide and fungicide treatments were applied in all trials when necessary.

\section{Microorganisms}

$\mathrm{Br}$ was individually used or mixed with PGPR, which contained Azospirillum brasilense (NO 40) and Serratia marcescens (EG 10). Br was cultured in a yeast extract mannitol broth medium (Vincent 1970), and A. brasilense and S. marcescens were grown in Kings medium B (Atlas 1995). The cultures were incubated at $28^{\circ} \mathrm{C}$ for 3 days on a rotary shaker until the early log phase to ensure a population density of $10^{9} \mathrm{cfu} \cdot \mathrm{mL}^{-1}$ culture. Powdered vermiculite supplemented with $10 \%$ Irish peat was packed into polyethylene bags (200 g carrier per bag), then sealed and sterilized with gamma irradiation $\left(5.0 \times 10^{6} \mathrm{rads}\right) ; 120 \mathrm{~mL}$ of $\log$ phase bacterial culture were injected into each sterilized carrier to satisfy $60 \%$ of the maximal water holding capacity, then were mixed 
thoroughly and left for a week to cure (Badawi et al. 2011). All strains were mixed with cultivated seeds.

\section{Chlorophyll meter reading (SPAD values)}

The relative chlorophyll content was taken as the average value from 3 fully expanded leaves, as obtained from a portable SPAD-502 chlorophyll meter (Konica-Minolta, Osaka, Japan). Measurements were taken at $\mathrm{BBCH} 35$ (50\% of plants meets between rows) and at $\mathrm{BBCH} 85$ (main phase of ripening: about $50 \%$ of pods developed to final size are ripe).

\section{Biomass sampling}

Biomass sampling was performed 2 times, at $\mathrm{BBCH} 35$ and $\mathrm{BBCH} 85$. To determine fresh biomass, 3 plants were removed from each plot and weighed. Thereafter, samples were placed in an oven $\left(65^{\circ} \mathrm{C}\right)$ until there was no change in the plant dry weight. The dried plant samples were finely ground, and the $\mathrm{N}$ content was detected by using the micro-Kjeldahl method, as described by the AOAC (1980). Furthermore, the aboveground N uptake $\left(\mathrm{kg} \cdot \mathrm{ha}^{-1}\right)$ was calculated as the plant dry weight multiplied by the total $\mathrm{N}$ content.

\section{Determination of pod yield, seed yield, and shelling percentage}

At harvest time, random samples of 5 plants were taken from each plot to determine the average pod and seed yield. After pod drying, the pod and seed yield $\left(\mathrm{t} \cdot \mathrm{ha}^{-1}\right)$ as well as shelling (\%) were determined. The shelling percentage (\%) was calculated using the following equation:

Shelling $(\%)=$ seed yield $\cdot$ plant ${ }^{-1} /$ pod yield $\cdot$ plant $^{-1}$

\section{Spectral reflectance measurements}

A passive bi-directional reflectance sensor (tec5, Oberursel, Germany) measuring wavelengths between 302 and $1,148 \mathrm{~nm}$, with a bandwidth of $2 \mathrm{~nm}$ and connected to a portable computer and geographical positioning system (GPS), was used. The handheld FieldSpec sensor consists of 2 units. One was linked to a diffuser and measured the light radiation as a reference signal. The second unit measured the canopy reflectance with an optic fiber (Mistele and Schmidhalter 2008; Elsayed et al. 2015a,b), with an aperture of $12^{\circ}$ and a field of view of $0.2 \mathrm{~m}^{2}$ from $1 \mathrm{~m}$ of height. The sensor outputs were co-recorded along with the GPS coordinates when collecting information in the field. The actual sensor output was co-referenced and recorded for each position. Afterwards, readings within 1 plot were averaged to a single value per plot. The canopy reflectance was calculated with the readings from the spectrometer unit and corrected with a calibration factor obtained from a reference grey standard. Spectral measurements were mostly taken on sunny days at nadir direction approximately $0.75 \mathrm{~m}$ above the canopy. Readings were taken once during main stem elongation $(\mathrm{BBCH} 35)$ and ripening of fruits and seeds (BBCH 85).

\section{Statistical analysis}

Selection of spectral reflectance indices

In Table 1, 5 spectral indices from different sources are listed with the respective references. In this study, we calculated and tested both known and novel indices. A contour map analysis for all wavelengths of the hyperspectral passive sensor (from 302 to $1,048 \mathrm{~nm}$ ) was used to select

Table 1. Formula, index abbreviation, and references of the different spectral indices used in this study.

\begin{tabular}{|c|c|c|}
\hline $\begin{array}{c}\text { Spectral } \\
\text { reflectance indices }\end{array}$ & Formula & References \\
\hline $\begin{array}{c}\text { Normalized index } \\
\text { based on } 780 \text { and } \\
550 \mathrm{~nm}\end{array}$ & $\left(R_{780}-R_{550}\right) /\left(R_{780}+R_{550}\right)$ & $\begin{array}{c}\text { Gutiérrez et al. } \\
\text { (2010) }\end{array}$ \\
\hline $\begin{array}{c}\text { Normalized index } \\
\text { based on } 760 \text { and } \\
730 \mathrm{~nm}\end{array}$ & $\left(R_{760}-R_{730}\right) /\left(R_{760}+R_{730}\right)$ & $\begin{array}{l}\text { Barnes et al. } \\
\quad(2000)\end{array}$ \\
\hline $\begin{array}{c}\text { Normalized index } \\
\text { based on } 698 \text { and } \\
420 \mathrm{~nm}\end{array}$ & $\left(R_{698}-R_{420}\right) /\left(R_{698}+R_{420}\right)$ & $\begin{array}{l}\text { Elsayed et al. } \\
\quad(2015 a)\end{array}$ \\
\hline $\begin{array}{c}\text { Normalized index } \\
\text { based on } 660 \text { and } \\
440 \mathrm{~nm}\end{array}$ & $\left(R_{660}-R_{440}\right) /\left(R_{660}+R_{440}\right)$ & This study \\
\hline $\begin{array}{l}\text { Normalized index } \\
\text { based on } 640 \text { and } \\
470 \mathrm{~nm}\end{array}$ & $\left(R_{640}-R_{470}\right) /\left(R_{640}+R_{470}\right)$ & This study \\
\hline $\begin{array}{c}\text { Normalized index } \\
\text { based on } 610 \text { and } \\
424 \mathrm{~nm}\end{array}$ & $\left(R_{610}-R_{424}\right) /\left(R_{610}+R_{424}\right)$ & $\begin{array}{l}\text { Elsayed et al. } \\
\text { (2015a) }\end{array}$ \\
\hline $\begin{array}{c}\text { Normalized index } \\
\text { based on } 500 \text { and } \\
460 \mathrm{~nm}\end{array}$ & $\left(R_{500}-R_{460}\right) /\left(R_{500}+R_{460}\right)$ & $\begin{array}{l}\text { Elsayed et al. } \\
\quad(2015 a)\end{array}$ \\
\hline
\end{tabular}


some normalized difference indices (Figure 1). The "lattice" package from the R statistics software version 3.0.2 (R Foundation for Statistical Computing 2013) was used

(a)

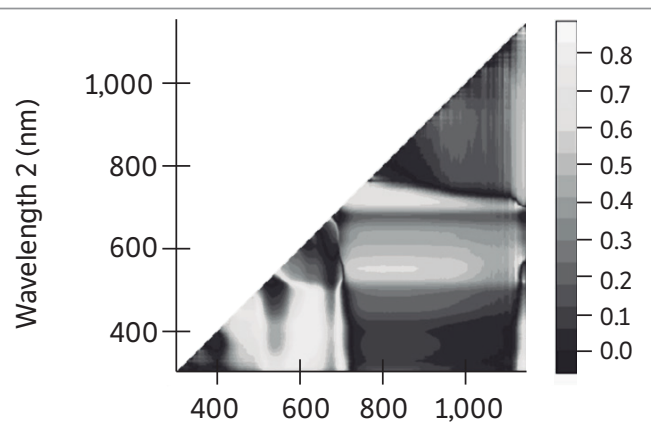

(b)

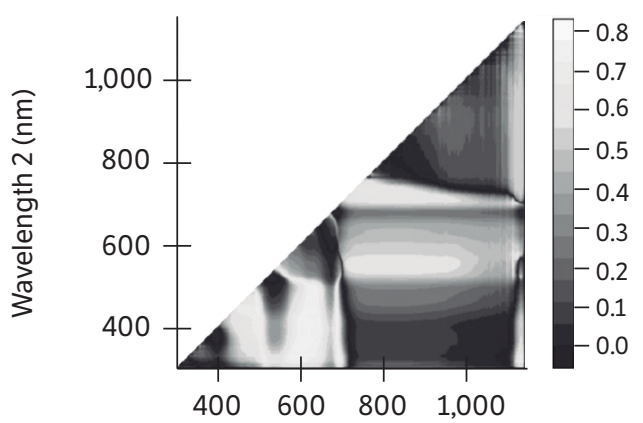

(c)

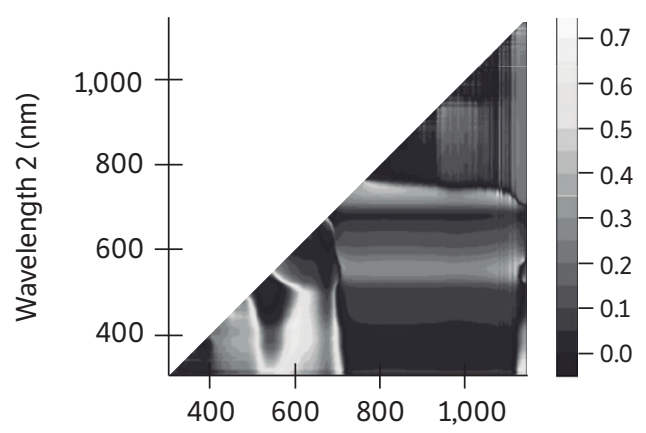

(d)

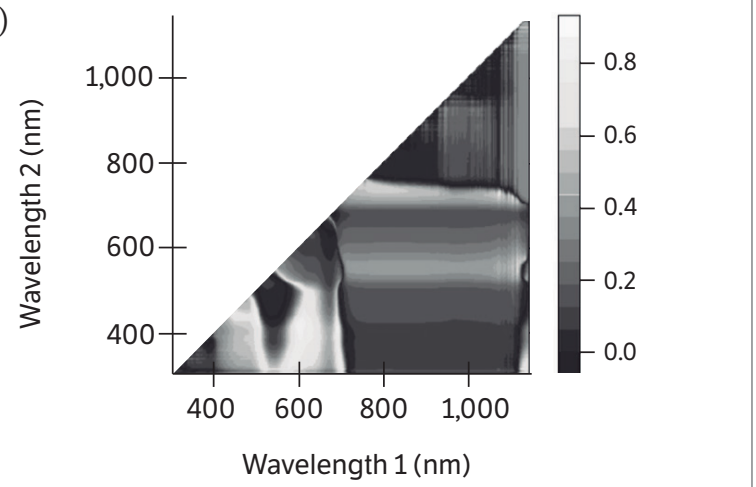

Figure 1. Correlation matrices (contour maps) showing the coefficients of determination $\left(R^{2}\right)$ for all dual wavelength combinations in the $302-$ $1,148 \mathrm{~nm}$ range (as a normalized difference index) of the hyperspectral passive reflectance sensing with (a) biomass fresh weight at $\mathrm{BBCH} 35$, (b) nitrogen uptake at $\mathrm{BBCH} 35$, (c) nitrogen concentration at $\mathrm{BBCH} 85$, and (d) seed yield at BBCH 85 of 2 peanut cultivars. to produce the contour maps from the hyperspectral reflectance readings; 12 wavelengths $(780 ; 760 ; 730$; $698 ; 660 ; 640 ; 610 ; 550 ; 500 ; 470 ; 460$ and $420 \mathrm{~nm})$ were therefore used to calculate the reflectance indices given in Table 1.

\section{Modelling of measured plant traits}

Sigmaplot for Windows v.12 (Systat software Inc., Chicago, IL, USA) and SPSS 22 (SPSS Inc., Chicago, IL, USA) were used for the statistical analysis. The Unscrambler $\mathrm{X}$ multivariate data analysis software version 10.2 (CAMO Software AS, Oslo, Norway) was used to calibrate and validate partial least square models. Single wavebands derived from the same spectra usually contain redundant information (Elsayed et al. 2015b). The PLSR creates orthogonal latent variables across the input variables (single wavebands) and relates them to the variables measurements. It is a way to cope with redundancy in the input variables, searching the sensitive information from the spectral reflectance for all wavelengths (Sharabian et al. 2014).

\section{RESULTS AND DISCUSSION Measured plant properties of peanut cultivars}

Mean values of the measured variables, i.e. biomass fresh and dry weight, nitrogen concentration, nitrogen uptake, SPAD value, pod and seed yield, and shelling percentage of the 2 peanut cultivars subjected to 3 levels of nitrogen fertilizer application with and without $\mathrm{Br}$ and PGPR are shown in Tables 2-4, and the data of nitrogen status are not shown at $\mathrm{BBCH} 85$. Generally, the highest mean values of all variables were recorded with the highest nitrogen level with $\mathrm{Br}$ and PGPR (N3 + Br + PGPR) for both cultivars, and the lowest values for the measured variables were recorded at the lowest nitrogen level (N1) without $\mathrm{Br}$ and PGPR. This could be due to the essential role of $\mathrm{Br}$ in enhancing plant growth and $\mathrm{N}_{2}$ fixation (Mekhemar et al. 2005). In addition, this finding could be attributable to the ability of PGPR to promote plant growth by either facilitating the uptake of essential elements or modulating hormones, enzymes, and siderophores (Tilak et al. 2005; Verma et al. 2010; Badawi et al. 2011). The mean values of biomass fresh and dry weight and nitrogen 
uptake increased with plant development, while the mean values of nitrogen concentration decreased. The nitrogen concentrations of the 2 peanut cultivars decreased with plant development. These results agree with other reports
(Mistele and Schmidhalter 2008), indicating that the nitrogen concentration of plants is often the highest at early growth stages and subsequently decreases with plant development to the stage of senescence. This reduction

Table 2. Average biomass fresh weight and biomass dry weight at growth stages $\mathrm{BBCH} 35$ and $\mathrm{BBCH} 85$ of 2 peanut cultivars at 3 levels of nitrogen fertilizer application with or without the inoculation by Bradyrhizobium and plant growth-promoting rhizobacteria in 2013.

\begin{tabular}{|c|c|c|c|c|c|c|c|c|c|}
\hline Cultivars & Treatments & $\begin{array}{c}\text { BFW1 } \\
\left(t \cdot h a^{-1}\right)\end{array}$ & $\begin{array}{c}\text { SD1 } \\
\left(\mathbf{t} \cdot h \mathrm{a}^{-1}\right)\end{array}$ & $\begin{array}{c}\text { BFW/2 } \\
\left(t \cdot h a^{-1}\right)\end{array}$ & $\begin{array}{c}\text { SD2 } \\
\left(\mathrm{t} \cdot h \mathrm{a}^{-1}\right)\end{array}$ & $\begin{array}{c}\text { BDW1 } \\
\left(t \cdot h a^{-1}\right)\end{array}$ & $\begin{array}{c}\text { SD1 } \\
\left(\mathrm{t} \cdot h \mathrm{a}^{-1}\right)\end{array}$ & $\begin{array}{c}\text { BDW/2 } \\
\left(\mathrm{t} \cdot h \mathrm{a}^{-1}\right)\end{array}$ & $\begin{array}{c}\text { SD2 } \\
\left(t \cdot h a^{-1}\right)\end{array}$ \\
\hline \multirow{9}{*}{ Giza 5} & $\mathrm{~N} 1$ & $2.57 i$ & 0.18 & $10.24 \mathrm{i}-\mathrm{j}$ & 0.50 & $0.44 \mathrm{~h}$ & 0.04 & 2.69h-i & 0.05 \\
\hline & $\mathrm{N} 1+\mathrm{Br}$ & $3.49 f-i$ & 0.36 & 12.56h-i & 1.02 & $0.66 \mathrm{e}-\mathrm{h}$ & 0.06 & $3.36 \mathrm{~g}-\mathrm{h}$ & 0.15 \\
\hline & $\mathrm{N} 1+\mathrm{Br}+\mathrm{PGPR}$ & $4.10 \mathrm{~d}-\mathrm{g}$ & 0.08 & $14.78 \mathrm{~g}-\mathrm{h}$ & 1.28 & $0.73 d-f$ & 0.04 & $4.14 \mathrm{f}-\mathrm{g}$ & 0.86 \\
\hline & N2 & $3.24 \mathrm{~g}-\mathrm{i}$ & 0.10 & $13.56 \mathrm{~h}$ & 1.15 & $0.54 f-h$ & 0.03 & 3.41g-h & 0.25 \\
\hline & $\mathrm{N} 2+\mathrm{Br}$ & $4.09 d-g$ & 0.27 & $16.87 f-g$ & 0.72 & $0.71 \mathrm{e}-\mathrm{f}$ & 0.05 & $4.17 f-g$ & 0.09 \\
\hline & $\mathrm{N} 2+\mathrm{Br}+\mathrm{PGPR}$ & $4.92 \mathrm{~b}-\mathrm{e}$ & 0.24 & $22.23 c-d$ & 0.81 & $0.81 b-e$ & 0.03 & $5.49 b-d$ & 0.06 \\
\hline & N3 & $4.63 b-f$ & 0.13 & 17.27.9f & 1.59 & $0.82 \mathrm{~b}-\mathrm{e}$ & 0.07 & $4.60 \mathrm{e}-\mathrm{f}$ & 0.42 \\
\hline & $\mathrm{N} 3+\mathrm{Br}$ & $5.76 a-b$ & 0.23 & $24.19 a-c$ & 1.02 & $1.02 a-b$ & 0.03 & $6.12 b-c$ & 0.24 \\
\hline & $\mathrm{N} 3+\mathrm{Br}+\mathrm{PGPR}$ & $6.30 a$ & 0.19 & $26.56 a$ & 0.98 & $1.06 a$ & 0.09 & $7.07 a$ & 0.35 \\
\hline \multirow{9}{*}{ Giza 6} & N1 & $2.37 i$ & 0.21 & $5.89 \mathrm{k}$ & 2.15 & $0.46 \mathrm{~g}-\mathrm{h}$ & 0.07 & $1.60 \mathrm{j}$ & 0.71 \\
\hline & $\mathrm{N} 1+\mathrm{Br}$ & $3.05 \mathrm{~g}-\mathrm{i}$ & 0.37 & $8.84 \mathrm{i}$ & 0.35 & $0.55 f-h$ & 0.08 & $2.32 \mathrm{i}$ & 0.21 \\
\hline & $\mathrm{N} 1+\mathrm{Br}+\mathrm{PGPR}$ & $3.78 \mathrm{e}-\mathrm{h}$ & 0.33 & $10.88 \mathrm{i}-\mathrm{j}$ & 0.53 & $0.70 e-f$ & 0.05 & $2.70 h-i$ & 0.59 \\
\hline & N2 & 2.91h-i & 0.67 & $13.78 \mathrm{~h}$ & 2.54 & $0.52 f-h$ & 0.11 & $3.48 \mathrm{~g}-\mathrm{h}$ & 0.80 \\
\hline & $\mathrm{N} 2+\mathrm{Br}$ & 4.01d-h & 0.34 & $16.21 f-g$ & 0.36 & $0.67 e-g$ & 0.06 & $4.04 f-g$ & 0.58 \\
\hline & $\mathrm{N} 2+\mathrm{Br}+\mathrm{PGPR}$ & $4.51 c-f$ & 0.37 & $19.62 e$ & 1.14 & $0.80 c-e$ & 0.02 & $4.88 d-f$ & 0.30 \\
\hline & N3 & $4.79 b-c$ & 0.25 & 19.96d-e & 1.58 & 0.87a-e & 0.06 & $5.28 c-e$ & 0.68 \\
\hline & $\mathrm{N} 3+\mathrm{Br}$ & $5.11 b-d$ & 0.21 & $22.77 b-c$ & 1.69 & $0.94 a-d$ & 0.42 & $5.98 b-c$ & 0.77 \\
\hline & $\mathrm{N} 3+\mathrm{Br}+\mathrm{PGPR}$ & $5.53 a-c$ & 0.13 & $24.93 a-b$ & 1.30 & $0.98 a-c$ & 0.02 & 6.31a-b & 0.17 \\
\hline
\end{tabular}

Values with the same letter are not significantly different ( $p \geq 0.05$ ) among treatments according to Duncan's test. BFW1 = Biomass fresh weight at BBCH 35; $\mathrm{SD}=$ Standard deviation; BFW2 = Biomass fresh weight at $\mathrm{BBCH} 85 ; \mathrm{BDW} 1=$ Biomass dry weight at BBCH 35; BDW2 = Biomass dry weight at BBCH 85; $\mathrm{Br}=$ Bradyrhizobium; PGPR = Plant growth-promoting rhizobacteria.

Table 3. Average nitrogen concentration, nitrogen uptake, and SPAD values of 2 peanut cultivars at 3 levels of nitrogen fertilizer application inoculated with or without Bradyrhizobium and plant growth-promoting rhizobacteria at BBCH 35 in 2013.

\begin{tabular}{|c|c|c|c|c|c|c|c|}
\hline Cultivars & Treatments & $\begin{array}{c}\text { Nitrogen } \\
(\%)\end{array}$ & $\begin{array}{l}\text { SD } \\
(\%)\end{array}$ & $\begin{array}{l}\text { N uptake } \\
\left(\mathrm{kg}^{\prime} \cdot \mathrm{ha}^{-1}\right)\end{array}$ & $\begin{array}{c}\text { SD } \\
\left(\mathrm{kg}^{\prime} \cdot \mathrm{ha}^{-1}\right)\end{array}$ & $\begin{array}{l}\text { SPAD } \\
\text { value }\end{array}$ & SD \\
\hline \multirow{9}{*}{ Giza 5} & N1 & $2.35 f-g$ & 0.20 & $10.42 i$ & 0.61 & 41.67g-h & 3.06 \\
\hline & $\mathrm{N} 1+\mathrm{Br}$ & $2.48 \mathrm{e}-\mathrm{h}$ & 0.28 & $16.37 g-i$ & 1.46 & $42.67 f-h$ & 1.53 \\
\hline & $\mathrm{N} 1+\mathrm{Br}+\mathrm{PGPR}$ & $2.52 \mathrm{e}-\mathrm{g}$ & 0.05 & $18.39 \mathrm{e}-\mathrm{h}$ & 0.63 & $42.00 \mathrm{~g}-\mathrm{h}$ & 0.50 \\
\hline & N2 & $2.58 \mathrm{~d}-\mathrm{g}$ & 0.06 & $13.89 \mathrm{~g}-\mathrm{i}$ & 0.35 & $44.33 e-h$ & 1.53 \\
\hline & $\mathrm{N} 2+\mathrm{Br}$ & $2.74 b-e$ & 0.25 & $19.43 \mathrm{~d}-\mathrm{g}$ & 1.04 & 47.33a-e & 2.08 \\
\hline & $\mathrm{N} 2+\mathrm{Br}+\mathrm{PGPR}$ & 2.87a-d & 0.24 & $23.26 c-f$ & 1.13 & $45.33 d-g$ & 2.31 \\
\hline & N3 & 2.97a-c & 0.17 & $30.43 a-b$ & 2.36 & $49.00 a-d$ & 3.00 \\
\hline & $\mathrm{N} 3+\mathrm{Br}$ & $3.08 a-b$ & 0.15 & $32.68 a$ & 1.94 & 49.67a-c & 0.58 \\
\hline & $\mathrm{N} 3+\mathrm{Br}+\mathrm{PGPR}$ & $3.12 a$ & 0.34 & $25.43 b-d$ & 2.48 & $50.00 a-b$ & 1.73 \\
\hline \multirow{9}{*}{ Giza 6} & N1 & $2.16 \mathrm{~h}$ & 0.13 & $9.84 i$ & 1.39 & $41.33 \mathrm{~h}$ & 1.53 \\
\hline & $\mathrm{N} 1+\mathrm{Br}$ & $2.27 \mathrm{~g}-\mathrm{h}$ & 0.06 & $12.51 \mathrm{~h}-\mathrm{i}$ & 1.99 & $41.33 \mathrm{~h}$ & 0.58 \\
\hline & $\mathrm{N} 1+\mathrm{Br}+\mathrm{PGPR}$ & $2.48 \mathrm{e}-\mathrm{h}$ & 0.05 & $17.39 f-h$ & 1.05 & $42.67 f-h$ & 0.58 \\
\hline & N2 & $2.51 \mathrm{e}-\mathrm{g}$ & 0.21 & $12.90 \mathrm{~g}-\mathrm{i}$ & 2.02 & $46.00 c-f$ & 4.58 \\
\hline & $\mathrm{N} 2+\mathrm{Br}$ & $2.65 c-f$ & 0.12 & $17.86 \mathrm{e}-\mathrm{h}$ & 1.74 & $44.33 e-h$ & 0.58 \\
\hline & $\mathrm{N} 2+\mathrm{Br}+\mathrm{PGPR}$ & 2.79a-e & 0.12 & 24.22b-e & 1.31 & 47.33a-e & 1.53 \\
\hline & N3 & 2.91a-d & 0.21 & $23.10 c-f$ & 2.02 & 47.00b-e & 1.00 \\
\hline & $\mathrm{N} 3+\mathrm{Br}$ & $2.96 a-c$ & 0.12 & $29.14 a-c$ & 1.81 & 48.00a-e & 1.00 \\
\hline & $\mathrm{N} 3+\mathrm{Br}+\mathrm{PGPR}$ & $3.03 a-b$ & 0.14 & $28.75 a-c$ & 3.07 & $51.00 a$ & 1.73 \\
\hline
\end{tabular}

Values with the same letter are not significantly different $(p \geq 0.05)$ among treatments according to Duncan's test. SD = Standard deviation; $B r=B r a d y r h i z o b i u m$; PGPR = Plant growth-promoting rhizobacteria. 
Table 4. Average pod yield, seed yield, and shelling percentage of 2 peanut cultivars at 3 levels of nitrogen fertilizer application inoculated with or without Bradyrhizobium and plant growth-promoting rhizobacteria in 2013.

\begin{tabular}{|c|c|c|c|c|c|c|c|}
\hline Cultivars & Treatments & $\begin{array}{l}\text { Pod yield } \\
\left(t \cdot h a^{-1}\right)\end{array}$ & $\begin{array}{c}\text { SD } \\
\left(t \cdot h a^{-1}\right)\end{array}$ & $\begin{array}{c}\text { Seed yield } \\
\left(t \cdot h a^{-1}\right)\end{array}$ & $\begin{array}{c}\text { SD } \\
\left(t \cdot h a^{-1}\right)\end{array}$ & $\begin{array}{c}\text { Shelling } \\
(\%)\end{array}$ & $\begin{array}{l}\text { SD } \\
(\%)\end{array}$ \\
\hline \multirow{9}{*}{ Giza 5} & $\mathrm{~N} 1$ & $2.41 \mathrm{f}-\mathrm{g}$ & 0.093 & $1.57 \mathrm{~h}-\mathrm{i}$ & 0.069 & $0.65 \mathrm{~h}$ & 0.008 \\
\hline & $\mathrm{N} 1+\mathrm{Br}$ & $2.74 d-e$ & 0.119 & $1.81 \mathrm{f}-\mathrm{g}$ & 0.092 & $0.66 f-h$ & 0.006 \\
\hline & $\mathrm{N} 1+\mathrm{Br}+\mathrm{PGPR}$ & $2.84 d$ & 0.152 & $1.88 \mathrm{e}-\mathrm{f}$ & 0.093 & $0.66 \mathrm{e}-\mathrm{h}$ & 0.003 \\
\hline & N2 & $2.51 \mathrm{e}-\mathrm{g}$ & 0.057 & $1.69 g-h$ & 0.031 & $0.67 d-g$ & 0.008 \\
\hline & $\mathrm{N} 2+\mathrm{Br}$ & $3.20 a-b$ & 0.176 & $2.17 b-d$ & 0.123 & 0.68d-e & 0.005 \\
\hline & $\mathrm{N} 2+\mathrm{Br}+\mathrm{PGPR}$ & $3.40 a$ & 0.110 & $2.33 a-b$ & 0.087 & $0.68 c-d$ & 0.005 \\
\hline & N3 & $3.07 b-c$ & 0.182 & $2.13 c-d$ & 0.112 & $0.70 a-c$ & 0.015 \\
\hline & $\mathrm{N} 3+\mathrm{Br}$ & $3.28 a-b$ & 0.245 & $2.32 a-b$ & 0.203 & $0.71 a-b$ & 0.014 \\
\hline & $\mathrm{N} 3+\mathrm{Br}+\mathrm{PGPR}$ & $3.41 a$ & 0.136 & $2.42 a$ & 0.069 & $0.71 a$ & 0.010 \\
\hline \multirow{9}{*}{ Giza 6} & $\mathrm{~N} 1$ & $2.00 \mathrm{i}$ & 0.177 & $1.29 \mathrm{j}$ & 0.099 & $0.65 h$ & 0.008 \\
\hline & $\mathrm{N} 1+\mathrm{Br}$ & $2.16 \mathrm{~h}-\mathrm{i}$ & 0.147 & $1.42 \mathrm{i}-\mathrm{j}$ & 0.104 & $0.66 \mathrm{~g}-\mathrm{h}$ & 0.006 \\
\hline & $\mathrm{N} 1+\mathrm{Br}+\mathrm{PGPR}$ & $2.30 \mathrm{~g}-\mathrm{h}$ & 0.086 & $1.52 \mathrm{i}$ & 0.050 & $0.66 f-h$ & 0.003 \\
\hline & $\mathrm{N} 2$ & $2.13 h-i$ & 0.116 & $1.43 i-j$ & 0.088 & $0.67 d-g$ & 0.008 \\
\hline & $\mathrm{N} 2+\mathrm{Br}$ & $2.56 \mathrm{e}-\mathrm{f}$ & 0.057 & $1.72 \mathrm{f}-\mathrm{h}$ & 0.051 & $0.67 d-f$ & 0.005 \\
\hline & $\mathrm{N} 2+\mathrm{Br}+\mathrm{PGPR}$ & $2.64 d-f$ & 0.051 & $1.80 \mathrm{f}-\mathrm{g}$ & 0.031 & $0.68 c-d$ & 0.005 \\
\hline & N3 & $2.41 \mathrm{f}-\mathrm{g}$ & 0.027 & $1.57 \mathrm{~b}-\mathrm{c}$ & 0.022 & $0.71 a-b$ & 0.010 \\
\hline & $\mathrm{N} 3+\mathrm{Br}$ & $2.55 \mathrm{e}-\mathrm{f}$ & 0.128 & $1.76 f-g$ & 0.089 & $0.69 b-c$ & 0.015 \\
\hline & $\mathrm{N} 3+\mathrm{Br}+\mathrm{PGPR}$ & $2.87 c-d$ & 0.117 & $2.02 d-e$ & 0.053 & $0.71 a-b$ & 0.014 \\
\hline
\end{tabular}

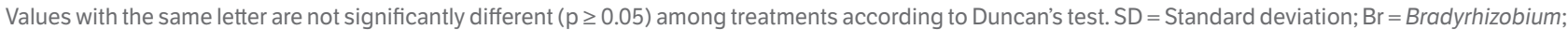
$\mathrm{PGPR}=$ Plant growth-promoting rhizobacteria.

in nitrogen concentration is interpreted as a dilution effect. Generally, the interaction between $\mathrm{Br}$ and PGPR tended to increase the biomass and nitrogen status of the 2 peanut cultivars. The Giza 5 peanut cultivar produced the highest pod and seed yield through all treatments compared to Giza 6.

\section{Influence of 3 levels of nitrogen fertilizer applications together with Bradyrhizobium and plant growth-promoting rhizobacteria on 4 spectral indices}

The 4 selected spectral reflectance indices used to assess the peanut cultivars were generally influenced by the 3 levels of nitrogen fertilizer applications with $\mathrm{Br}$ and PGPR (Table 5; the data of spectral indices at BBCH 35 are not shown). There was variability in the values of the spectral reflectance indices between the treatments at the same level of nitrogen fertilizer application at 2 different growth stages. The values of the spectral reflectance indices differed at the same level of nitrogen fertilizer application for the $\mathrm{Br}$ inoculation and for the co-inoculation of $\mathrm{Br}$ and
PGPR. For example, the values of the spectral reflectance indices $\left(\mathrm{R}_{500}-\mathrm{R}_{460}\right) /\left(\mathrm{R}_{500}+\mathrm{R}_{460}\right) ;\left(\mathrm{R}_{610}-\mathrm{R}_{422}\right) /\left(\mathrm{R}_{610}+\mathrm{R}_{422}\right)$; $\left(\mathrm{R}_{692}-\mathrm{R}_{420}\right) /\left(\mathrm{R}_{692}+\mathrm{R}_{420}\right)$ and $\left(\mathrm{R}_{760}-\mathrm{R}_{730}\right) /\left(\mathrm{R}_{760}+\mathrm{R}_{730}\right)$ of Giza 5 at $\mathrm{BBCH} 35$ under the lowest level of nitrogen fertilizer application varied from 0.073 to 0.090 , from 0.433 to 0.498 , from 0.398 to 0.507 , and from 0.083 to 0.128 , respectively. There were also clear differences in the values of the spectral reflectance indices between all treatments for the 2 cultivars. These differences between inoculated and non-inoculated peanut plants at the same level of nitrogen may be due to the ability of Br and PGPR to increase the biomass due to enhanced nutrient uptake (Verma et al. 2010; Badawi et al. 2011). The values of the spectral indices ranged from 0.053 to 0.107 ; from 0.33 to 0.527 ; from 0.307 to 0.562 and from 0.063 to 0.180 for $\left(\mathrm{R}_{500}-\mathrm{R}_{460}\right) /\left(\mathrm{R}_{500}+\mathrm{R}_{460}\right) ;\left(\mathrm{R}_{610}-\mathrm{R}_{422}\right) /\left(\mathrm{R}_{610}+\mathrm{R}_{422}\right)$; $\left(\mathrm{R}_{692}-\mathrm{R}_{420}\right) /\left(\mathrm{R}_{692}+\mathrm{R}_{420}\right)$ and $\left(\mathrm{R}_{760}-\mathrm{R}_{730}\right) /\left(\mathrm{R}_{760}+\mathrm{R}_{730}\right)$; respectively. The values of 3 spectral indice, $\left(R_{500}-R_{460}\right) /$ $\left(\mathrm{R}_{500}+\mathrm{R}_{460}\right) ;\left(\mathrm{R}_{610}-\mathrm{R}_{422}\right) /\left(\mathrm{R}_{610}+\mathrm{R}_{422}\right) ;$ and $\left(\mathrm{R}_{692}-\mathrm{R}_{420}\right) /$ $\left(\mathrm{R}_{692}+\mathrm{R}_{420}\right)$ decreased, while the spectral index $\left(\mathrm{R}_{760}-\mathrm{R}_{730}\right) /$ $\left(\mathrm{R}_{760}+\mathrm{R}_{730}\right)$ value increased with increasing nitrogen levels. 
Table 5. Values of 4 spectral reflectance indices of peanut cultivars as affected by 3 levels of nitrogen fertilizer with or without Bradyrhizobium and plant growth-promoting rhizobacteria at $\mathrm{BBCH} 85$.

\begin{tabular}{|c|c|c|c|c|c|c|c|c|c|}
\hline Cultivars & Treatments & $\begin{array}{c}\left(\mathbf{R}_{500}-\mathbf{R}_{460}\right) / \\
\left(\mathbf{R}_{500}+\mathbf{R}_{460}\right)\end{array}$ & SD & $\begin{array}{l}\left(\mathbf{R}_{610}-\mathbf{R}_{424}\right) / \\
\left(\mathbf{R}_{610}+\mathbf{R}_{424}\right)\end{array}$ & SD & $\begin{array}{l}\left(\mathbf{R}_{692}-\mathbf{R}_{420}\right) / \\
\left(\mathbf{R}_{692}+\mathbf{R}_{420}\right)\end{array}$ & SD & $\begin{array}{l}\left(\mathbf{R}_{760}-\mathbf{R}_{730}\right) / \\
\left(\mathbf{R}_{760}+\mathbf{R}_{730}\right)\end{array}$ & SD \\
\hline \multirow{9}{*}{ Giza 5} & N1 & $0.090 \mathrm{~b}$ & 0.001 & $0.498 c$ & 0.007 & $0.507 a-b$ & 0.051 & $0.083 c-e$ & 0.038 \\
\hline & $\mathrm{N} 1+\mathrm{Br}$ & $0.076 c$ & 0.000 & $0.447 e$ & 0.002 & $0.428 c-d$ & 0.003 & $0.133 a-b$ & 0.001 \\
\hline & $\mathrm{N} 1+\mathrm{Br}+\mathrm{PGPR}$ & $0.073 c-d$ & 0.000 & $0.433 \mathrm{e}-\mathrm{g}$ & 0.001 & $0.398 d-e$ & 0.002 & $0.128 a-d$ & 0.000 \\
\hline & $\mathrm{N} 2$ & $0.073 c-d$ & 0.005 & $0.442 e-f$ & 0.017 & $0.422 c-d$ & 0.028 & $0.140 a$ & 0.015 \\
\hline & $\mathrm{N} 2+\mathrm{Br}$ & $0.070 c-e$ & 0.001 & $0.419 f$ & 0.003 & $0.391 d-e$ & 0.004 & $0.159 a$ & 0.010 \\
\hline & $\mathrm{N} 2+\mathrm{Br}+\mathrm{PGPR}$ & $0.055 f$ & 0.002 & $0.349 \mathrm{i}-\mathrm{j}$ & 0.006 & $0.326 \mathrm{e}$ & 0.010 & $0.172 a$ & 0.004 \\
\hline & N3 & $0.072 c-e$ & 0.001 & $0.420 f-g$ & 0.004 & $0.395 \mathrm{~d}-\mathrm{e}$ & 0.004 & $0.154 a$ & 0.015 \\
\hline & $\mathrm{N} 3+\mathrm{Br}$ & $0.059 \mathrm{f}-\mathrm{g}$ & 0.004 & $0.365 i$ & 0.018 & $0.342 \mathrm{e}-\mathrm{f}$ & 0.017 & $0.168 a$ & 0.010 \\
\hline & $\mathrm{N} 3+\mathrm{Br}+\mathrm{PGPR}$ & $0.053 f$ & 0.005 & $0.330 \mathrm{j}$ & 0.022 & $0.307 e$ & 0.021 & $0.180 a$ & 0.012 \\
\hline \multirow{9}{*}{ Giza 6} & $\mathrm{~N} 1$ & $0.106 a$ & 0.001 & $0.556 a$ & 0.015 & $0.542 b$ & 0.017 & $0.082 \mathrm{~d}-\mathrm{e}$ & 0.006 \\
\hline & $\mathrm{N} 1+\mathrm{Br}$ & $0.093 b$ & 0.007 & $0.530 \mathrm{~b}$ & 0.003 & $0.529 a-b$ & 0.032 & 0.091b-e & 0.037 \\
\hline & $\mathrm{N} 1+\mathrm{Br}+\mathrm{PGPR}$ & $0.088 b$ & 0.001 & $0.490 c-d$ & 0.002 & $0.473 b-c$ & 0.008 & $0.132 a-c$ & 0.005 \\
\hline & N2 & $0.094 b$ & 0.006 & $0.492 c$ & 0.001 & $0.562 a$ & 0.077 & $0.063 e$ & 0.056 \\
\hline & $\mathrm{N} 2+\mathrm{Br}$ & $0.087 \mathrm{~b}$ & 0.008 & $0.471 d$ & 0.015 & $0.525 a-b$ & 0.102 & $0.083 c-e$ & 0.077 \\
\hline & $\mathrm{N} 2+\mathrm{Br}+\mathrm{PGPR}$ & $0.075 c$ & 0.007 & $0.432 \mathrm{e}-\mathrm{g}$ & 0.012 & $0.421 c-d$ & 0.008 & $0.132 a-c$ & 0.008 \\
\hline & N3 & $0.066 \mathrm{~d}-\mathrm{f}$ & 0.003 & $0.414 \mathrm{~g}-\mathrm{h}$ & 0.004 & $0.398 \mathrm{~d}-\mathrm{e}$ & 0.012 & $0.142 a$ & 0.005 \\
\hline & $\mathrm{N} 3+\mathrm{Br}$ & $0.065 e-f$ & 0.002 & $0.395 \mathrm{~h}$ & 0.012 & $0.370 d-f$ & 0.012 & $0.156 a$ & 0.005 \\
\hline & $\mathrm{N} 3+\mathrm{Br}+\mathrm{PGPR}$ & $0.056 f$ & 0.005 & $0.353 \mathrm{i}$ & 0.019 & $0.334 \mathrm{e}-\mathrm{f}$ & 0.017 & $0.176 a$ & 0.009 \\
\hline
\end{tabular}

Values with the same letter are not significantly different $(\mathrm{p} \geq 0.05)$ among treatments according to Duncan's test. SD $=\mathrm{Standard}$ deviation; $\mathrm{Br}=\mathrm{Bradyrhizobium;}$ PGPR = Plant growth-promoting rhizobacteria.

\section{Contour map analysis of the hyperspectral passive data}

A contour map analysis produced the mean coefficients of determination $\left(\mathrm{R}^{2}\right)$ of the 2 measurement dates for all dual wavelength combinations as a normalized difference spectral index. The contours of the matrices of the hyperspectral passive sensor presented more distinct relationships between measure plant parameters, such as biomass dry weight, nitrogen concentration, nitrogen uptake, SPAD value, pod yield, seed yield, and shelling percentage of the peanut cultivars with visible wavelengths than with the combination of visible and near infrared wavelengths. The contour map analysis of the relationship between the normalized difference spectral indices with biomass fresh weight and nitrogen uptake at $\mathrm{BBCH} 35$ as well as nitrogen concentration and seed yield at $\mathrm{BBCH} 85$ are shown in Figure 1.

The averages of the correlation matrices resulting from the measurements at 2 growth stages - indicated by the coefficients of determination $\left(\mathrm{R}^{2}\right)$ for all dual wavelengths combinations of $400-780 \mathrm{~nm}$ as normalised difference indices for all measured parameters of the 2 peanut cultivars - presented higher $\mathrm{R}^{2}$ values compared to all other 2 wavelength combinations
(Figure 1). This may be due 400 to $750 \mathrm{~nm}$ being more affected by chlorophyll- $a$ and chlorophyll- $b$ as well as the leaf area index. These findings agree with results of Townsend et al. (2003), who reported relatively low reflectance from the 400 to $530 \mathrm{~nm}$ blue region rapidly changing to higher reflectance in the green region and edge of the red region, from 680 to $730 \mathrm{~nm}$. The spectra in the 450 to $530 \mathrm{~nm}$ range are strongly influenced by the presence and abundance of chlorophyll- $a$ and chlorophyll- $b$. In contrast, the spectra in the 680 to 730 $\mathrm{nm}$ range may be correlated with the leaf area index. Therefore, peanut cultivars exposed to different levels of nitrogen with or without $\mathrm{Br}$ and PGPR create a significant variation in spectral measurements from 400 to $750 \mathrm{~nm}$.

\section{Relationship between spectral reflectance indices with different measured plant parameters}

Across the 2 measuring dates, 7 spectral indices were more closely correlated with biomass dry weight, biomass fresh weight, nitrogen concentration, nitrogen uptake, SPAD value, pod yield, seed yield, and shelling percentage of the 2 peanut 
cultivars. The obtained coefficients of determination $\left(\mathrm{R}^{2}\right)$ are shown in Table 6. Statistically significant relationships between all spectral reflectance indices derived from the visible (VIS), near infrared (NIR) or the combination of VIS and NIR regions were found for biomass dry weight $\left(\mathrm{R}^{2}\right.$ values ranging from $0.60^{* * *}$ to $\left.0.86^{* * *}\right)$, biomass fresh weight $\left(\mathrm{R}^{2}\right.$ values ranging from $0.62^{* * *}$ to $\left.0.89^{* * *}\right)$, nitrogen concentration $\left(\mathrm{R}^{2}\right.$ values ranging from $0.49^{* * *}$ to $\left.0.68^{* * *}\right)$, nitrogen uptake $\left(\mathrm{R}^{2}\right.$ values ranging from $0.63^{* *}$ to $\left.0.84^{* * *}\right)$, SPAD value $\left(\mathrm{R}^{2}\right.$ values ranging from $0.55^{* * *}$ to $\left.0.67^{* * *}\right)$, pod yield $\left(\mathrm{R}^{2}\right.$ values ranging from $0.47^{* * *}$ to $0.83^{* * *}$ ), seed yield ( $\mathrm{R}^{2}$ values ranging from $0.49^{* * *}$ to $\left.0.86^{* * *}\right)$, and shelling percentage $\left(R^{2}\right.$ values ranging from $0.58^{* * *}$ to $0.871^{* * *}$ ), as shown in Table 6. Generally, the normalized spectral indices of $\left(\mathrm{R}_{610}-\mathrm{R}_{424}\right) /\left(\mathrm{R}_{610}+\mathrm{R}_{424}\right)$ and $\left(\mathrm{R}_{692}-\mathrm{R}_{420}\right) /$ $\left(R_{692}+R_{420}\right)$ showed the highest coefficients of determination for most of the measured variables at the 2 growth stages. The highest coefficients of determination $\left(\mathrm{R}^{2}\right)$ for most variables were found at $\mathrm{BBCH} 85$ compared to $\mathrm{BBCH} 35$.

The results demonstrated that the selected 7 spectral reflectance indices (Table 1) were apparently useful for monitoring the measured parameters (Table 6). The results also presented that, based on $\mathrm{R}^{2}$ for pod and seed yield, it was better to monitor both parameters at $\mathrm{BBCH} 85$ than at $\mathrm{BBCH} 35$. These results agree with Elsayed et al. (2015a), who found that the normalized spectral index of $\left(\mathrm{R}_{610}-\mathrm{R}_{424}\right) /\left(\mathrm{R}_{610}+\mathrm{R}_{424}\right)$ showed the highest $\mathrm{R}^{2}$ values $\left(0.70^{* * *}\right.$, $0.69^{* * *}$, and $0.53^{* * *}$ ) for pod yield, seed protein content, and straw yield of peanut cultivars, respectively, at BBCH 85 . Importantly, the 3 spectral indices that were derived from the VIS, $\left(\mathrm{R}_{610}-\mathrm{R}_{424}\right) /\left(\mathrm{R}_{610}+\mathrm{R}_{424}\right) ;\left(\mathrm{R}_{698}-\mathrm{R}_{420}\right) /\left(\mathrm{R}_{698}+\mathrm{R}_{420}\right)$ and $\left(\mathrm{R}_{640}-\mathrm{R}_{470}\right) /\left(\mathrm{R}_{640}+\mathrm{R}_{470}\right)$, had $\mathrm{R}^{2}$ values up to $0.89^{* * *}$, meaning they were more closely related to the measured parameters compared to indices derived from the NIR range or the combination between VIS and NIR regions, $\left(\mathrm{R}_{760}-\mathrm{R}_{730}\right)$ / $\left(\mathrm{R}_{760}+\mathrm{R}_{730}\right)$ and $\left(\mathrm{R}_{780}-\mathrm{R}_{550}\right) /\left(\mathrm{R}_{780}+\mathrm{R}_{550}\right)$, which had $\mathrm{R}^{2}$ values up to $0.77^{* * *}$ (Table 6 ).

The curves of the relationships between nitrogen percentage, nitrogen uptake, and SPAD values and the index $\left(\mathrm{R}_{610}-\mathrm{R}_{424}\right) /\left(\mathrm{R}_{610}+\mathrm{R}_{424}\right)$ at the 2 stages showed a shift in the values and different slopes (Figure 2). This may be due to the plant development through the growth stages, which leads to changes in the structure of peanut plants.

Table 6. Coefficients of determination of linear regressions of biomass dry weight, biomass fresh weight, nitrogen concentration, nitrogen uptake, SPAD value, pod and seed yield and shelling percentage of peanut cultivars with spectral reflectance indices obtained from hyperspectral passive sensing (calculated as normalized difference indices) for peanut cultivars subjected to 3 levels of nitrogen fertilizer application with or without Bradyrhizobium and plant growth-promoting rhizobacteria at $\mathrm{BBCH} 35$ and 85.

\begin{tabular}{|c|c|c|c|c|c|c|c|c|}
\hline $\begin{array}{l}\text { Growth } \\
\text { stage }\end{array}$ & Parameters & $\begin{array}{c}\left(R_{500}-R_{460}\right) / \\
\left(R_{500}+R_{460}\right)\end{array}$ & $\begin{array}{c}\left(R_{610}-R_{422}\right) / \\
\left(R_{610}+R_{422}\right)\end{array}$ & $\begin{array}{c}\left(R_{698}-R_{420}\right) / \\
\left(R_{698}+R_{420}\right)\end{array}$ & $\begin{array}{l}\left(\mathbf{R}_{780}-\mathbf{R}_{550}\right) / \\
\left(\mathbf{R}_{780}+\mathbf{R}_{550}\right)\end{array}$ & $\begin{array}{c}\left(R_{760}-R_{730}\right) / \\
\left(R_{760}+R_{730}\right)\end{array}$ & $\begin{array}{c}\left(R_{660}-R_{440}\right) / \\
\left(R_{660}+R_{440}\right)\end{array}$ & $\begin{array}{l}\left(\mathbf{R}_{640}-\mathbf{R}_{470}\right) / \\
\left(\mathbf{R}_{640}+\mathbf{R}_{470}\right)\end{array}$ \\
\hline \multirow{8}{*}{ BBCH 35} & BDW & $0.78^{\star \star \star}$ & $0.82^{\star \star \star}$ & $0.82^{\star \star \star}$ & $0.65^{* \star \star}$ & $0.67^{\star \star \star}$ & $0.60^{* * *}$ & $0.72^{\star \star \star}$ \\
\hline & BFW & $0.71^{* * *}$ & $0.74^{* * *}$ & $0.74^{* * *}$ & $0.62^{* * *}$ & $0.63^{* * *}$ & $0.64^{* * *}$ & $0.78^{* * *}$ \\
\hline & $N$ & $0.50^{* \star *}$ & $0.50^{* \star *}$ & $0.53^{\star \star \star}$ & $0.50^{* * *}$ & $0.50^{* \star *}$ & $0.49^{* \star \star}$ & $0.53^{\star \star \star}$ \\
\hline & N uptake & $0.72^{* * *}$ & $0.75^{* * *}$ & $0.76^{* * *}$ & $0.63^{* * *}$ & $0.65^{* * *}$ & $0.63^{* * *}$ & $0.74^{* * *}$ \\
\hline & SPAD value & $0.64^{\star \star *}$ & $0.63^{\star * \star}$ & $0.62^{\star * \star}$ & $0.55^{\star \star \star}$ & $0.56^{\star \star \star}$ & $0.57^{\star \star *}$ & $0.63^{* * \star}$ \\
\hline & Pod yield & $0.61^{* \star *}$ & $0.65^{\star \star *}$ & $0.65^{* \star *}$ & $0.47^{\star \star *}$ & $0.49^{* * *}$ & $0.47^{\star \star *}$ & $0.59^{* * *}$ \\
\hline & Seed yield & $0.66^{\star \star *}$ & $0.70^{\star \star \star}$ & $0.70^{\star \star \star}$ & $0.53^{\star \star \star}$ & $0.56^{\star \star \star}$ & $0.49^{* * \star}$ & $0.65^{* \star *}$ \\
\hline & Shelling & $0.58^{\star \star *}$ & $0.58^{* \star *}$ & $0.61^{\star \star \star}$ & $0.61^{\star \star \star}$ & $0.65^{* \star *}$ & $0.60^{* * *}$ & $0.62^{\star * \star}$ \\
\hline \multirow{8}{*}{ BBCH 85} & BDW & $0.76^{\star \star \star}$ & $0.86^{\star \star \star}$ & $0.85^{* * *}$ & $0.68^{* * *}$ & $0.71^{* \star *}$ & $0.81^{* * *}$ & $0.80^{* * *}$ \\
\hline & BFW & $0.79^{* * *}$ & $0.89^{\star * *}$ & $0.88^{* * *}$ & $0.75^{\star \star \star}$ & $0.77^{\star \star *}$ & $0.86^{* \star *}$ & $0.86^{* * *}$ \\
\hline & $\mathrm{N}$ & $0.59^{\star \star \star *}$ & $0.66^{\star \star \star}$ & $0.68^{* \star *}$ & $0.65^{\star \star \star}$ & $0.68^{\star \star \star}$ & $0.66^{* \star}$ & $0.65^{\star \star \star}$ \\
\hline & N uptake & $0.75^{\star \star \star}$ & $0.84^{* * *}$ & $0.84^{* * *}$ & $0.68^{* * *}$ & $0.72^{* * *}$ & $0.81^{\star \star *}$ & $0.79^{\star \star *}$ \\
\hline & SPAD value & $0.61^{\star \star *}$ & $0.67^{\star \star *}$ & $0.65^{\star \star *}$ & $0.62^{\star * *}$ & $0.64^{\star \star \star}$ & $0.65^{* \star *}$ & $0.52^{\star * *}$ \\
\hline & Pod yield & $0.74^{* * *}$ & $0.82^{* * *}$ & $0.83^{* * *}$ & $0.62^{* * *}$ & $0.71^{* * *}$ & $0.75^{* * *}$ & $0.69^{* * *}$ \\
\hline & Seed yield & $0.78^{* \star *}$ & $0.85^{\star \star *}$ & $0.86^{* \star *}$ & $0.67^{\star \star *}$ & $0.76^{\star \star \star}$ & $0.81^{\star \star \star}$ & $0.75^{* \star \star}$ \\
\hline & Shelling & $0.63^{\star \star \star}$ & $0.66^{\star \star \star}$ & $0.66^{* \star *}$ & $0.61^{\star \star \star}$ & $0.62^{\star \star \star}$ & $0.71^{\star \star \star}$ & $0.63^{\star \star *}$ \\
\hline
\end{tabular}

${ }^{\star * *}$ Statistically significant at $\mathrm{p} \leq 0.001$. BDW $=$ Biomass dry weight; $\mathrm{BFW}=$ Biomass fresh weight. 


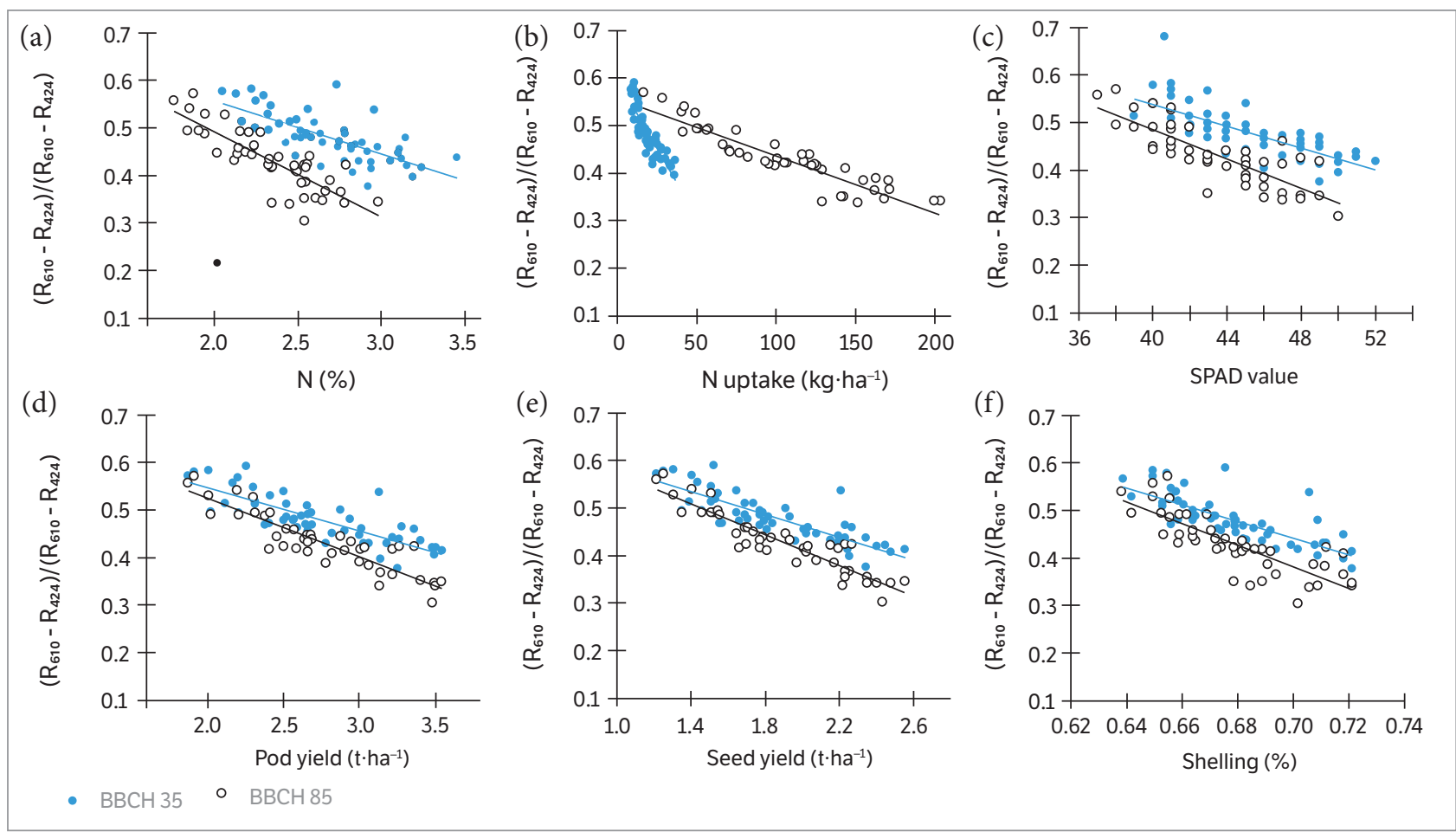

Figure 2. The relationship between the spectral index $\left(R_{610}-R_{424}\right) /\left(R_{610}+R_{424}\right)$ and (a) the nitrogen concentration, (b) the nitrogen uptake, (c) the SPAD value, (d) the pod yield, (e) the seed yield, and ( $f$ ) the shelling percentage of 2 peanut cultivars at 2 growth stages. Statistical information is given in Table 6 .

\section{Partial least square regression analysis to predict the different measurement variables}

In Table 7, as well as in Figures 3,4, the quality of the PLSR models is represented by adjusted coefficients of determination of calibration $\left(\mathrm{R}^{2} \mathrm{cal}\right)$ and validation $\left(\mathrm{R}^{2} \mathrm{val}\right)$, root mean square errors (RMSE cal and val), and the slope of the linear regressions for calibration and validation models at the 2 measurement dates. Across all calibration data set formations, the coefficients of determination varied from $0.69^{* * *}$ to $0.97^{* * *}$ for all parameters. Across all validation data set formations, the coefficients of determination varied from $0.38^{* * *}$ to $0.82^{* * * *}$ for all parameters. Across all calibration and validation data set formations, the RMSE varied from 0.07 to $0.87 \mathrm{t} \cdot \mathrm{ha}^{-1}$ for biomass dry weight, 0.30 to $2.52 \mathrm{t}^{\mathrm{t}} \mathrm{ha} \mathrm{a}^{-1}$ for biomass fresh weight, 0.06 to $0.26 \%$ for nitrogen concentration, 2.19 to $26.2 \mathrm{~kg} \cdot \mathrm{ha}^{-1}$ for nitrogen uptake, 1.37 to 2.31 for SPAD value, 0.12 to 0.3 th ha ${ }^{-1}$ pod yield, 0.09 to $0.20 \mathrm{t} \cdot \mathrm{ha}^{-1}$ for seed yield, and 0.01 to $0.014 \%$ for shelling percentage. The highest slopes for the calibration and validation data sets were 0.95 and 0.92 , respectively, across all measurements dates of biomass fresh weight at $\mathrm{BBCH} 85$ (Table 7).

The use of the full spectral range from 302 to $1,148 \mathrm{~nm}$ for the PLSR analysis increased the accuracy of the estimates of the measured parameters for the 2 peanut cultivars (Table 7) compared with the use of the normalized difference spectral indices (Table 6). The PLSR technique allowed the identification of optimized models and is considered the stateof-the art technique enabling a high efficiency in searching for optimized relationships. Simple linear, polynomial, or exponential functions are used to model the relationship between biophysical parameters and vegetation indices. Alternatively, non-linear regression techniques, such as support vector regression (SVR), have been applied. That experience indicates that overfitting should be avoided and more importance should be paid to the robustness of the tested algorithms. The advantage of PLSR models compared with spectral indices is that the PLSR in this study used information from every spectral band from 302 to $1,148 \mathrm{~nm}$ and selected the number of factors that better represent the calibration data without overfitting. PLSR had no limitation in predicting the measured parameters, and the relationship between the observed and predicted values was linear. The calibration model of the PLSR was strongly related to measured parameters compared to the normalized difference spectral indices. Comparably, in peanut cultivars, the assessment of measured parameters was stronger and more 
Table 7. Calibration, and 20 -fold cross-validation of the statistics of partial least square regression models of the spectral reflectance from 302 to $1,148 \mathrm{~nm}$ with biomass fresh weight, biomass dry weight, nitrogen concentration, nitrogen uptake, SPAD value, pod yield, seed yield, and shelling percentage of peanut cultivars.

\begin{tabular}{|c|c|c|c|c|c|c|c|c|c|c|c|c|c|c|c|c|c|}
\hline $\begin{array}{c}\text { Growth } \\
\text { stage }\end{array}$ & $\begin{array}{l}\text { Statistcal } \\
\text { parameters }\end{array}$ & PCs & DW & PCs & FW & PCs & $\mathbf{N}$ & PCs & $\begin{array}{c}\mathbf{N} \\
\text { uptake }\end{array}$ & PCs & $\begin{array}{l}\text { SPAD } \\
\text { value }\end{array}$ & PCs & $\begin{array}{l}\text { Pod } \\
\text { yield }\end{array}$ & PCs & $\begin{array}{l}\text { Seed } \\
\text { yield }\end{array}$ & PCs & Shelling \\
\hline \multirow[t]{6}{*}{$\mathrm{BBCH} 35$} & $\mathrm{R}^{2}$ cal & 6 & $0.90^{* * *}$ & 6 & $0.93^{* * \star}$ & 4 & $0.51^{\star \star *}$ & 6 & $0.92^{* * \star}$ & 6 & $0.83^{* * \star}$ & 8 & $0.93^{\star \star *}$ & 8 & $0.94^{\star \star \star}$ & 6 & $0.90^{* * *}$ \\
\hline & $\mathrm{R}^{2}$ val & & $0.67^{* * *}$ & & $0.76^{* * *}$ & & $0.43^{* * *}$ & & $0.74^{* * *}$ & & $0.52^{* * *}$ & & $0.60^{* * *}$ & & $0.68^{* * *}$ & & $0.64^{* * *}$ \\
\hline & RMSE cal & & 0.07 & & 0.30 & & 0.22 & & 2.19 & & 1.37 & & 0.12 & & 0.09 & & 0.01 \\
\hline & RMSE val & & 0.12 & & 0.60 & & 0.25 & & 3.93 & & 2.31 & & 0.30 & & 0.21 & & 0.01 \\
\hline & Slope cal & & 0.9 & & 0.93 & & 0.97 & & 0.92 & & 0.83 & & 0.93 & & 0.94 & & 0.91 \\
\hline & Slope val & & 0.76 & & 0.83 & & 0.71 & & 0.82 & & 0.66 & & 0.74 & & 0.76 & & 0.76 \\
\hline \multirow[t]{6}{*}{$\mathrm{BBCH} 85$} & $\mathrm{R}^{2}$ cal & 5 & $0.89^{* * *}$ & 7 & $0.95^{* * *}$ & 5 & $0.73^{* * *}$ & 11 & $0.94^{* * *}$ & 5 & $0.75^{\star * *}$ & 6 & $0.88^{* * *}$ & 6 & $0.90^{* * *}$ & 5 & $0.69^{* * *}$ \\
\hline & $\mathrm{R}^{2}$ val & & $0.69^{* * *}$ & & $0.82^{* * *}$ & & $0.61^{* * *}$ & & $0.71^{* * *}$ & & $0.67^{* *}$ & & $0.78^{* * *}$ & & $0.81^{* * *}$ & & $0.57^{* * *}$ \\
\hline & RMSE cal & & 0.52 & & 1.37 & & 0.15 & & 11.14 & & 1.63 & & 0.16 & & 0.12 & & 0.012 \\
\hline & RMSE val & & 0.87 & & 2.52 & & 0.18 & & 26.24 & & 1.98 & & 0.22 & & 0.16 & & 0.014 \\
\hline & Slope cal & & 0.89 & & 0.95 & & 0.54 & & 0.94 & & 0.75 & & 0.88 & & 0.90 & & 0.69 \\
\hline & Slope val & & 0.78 & & 0.92 & & 0.47 & & 0.83 & & 0.67 & & 0.83 & & 0.86 & & 0.66 \\
\hline
\end{tabular}

${ }^{* \star *}$ Statistically significant at $\mathrm{p} \leq 0.001 ; \mathrm{PC}=$ Number of latent variables; DW $=$ Dry weight; FW $=$ Fresh weight; $c$ al $=$ Calibration; val $=$ Validation .

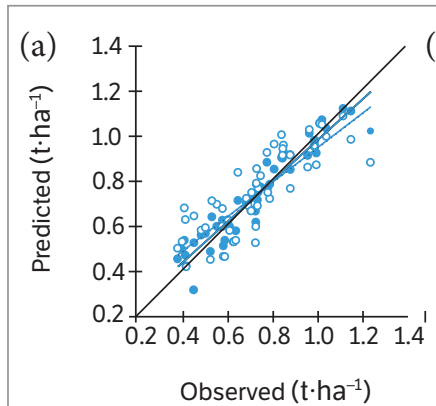

(e)

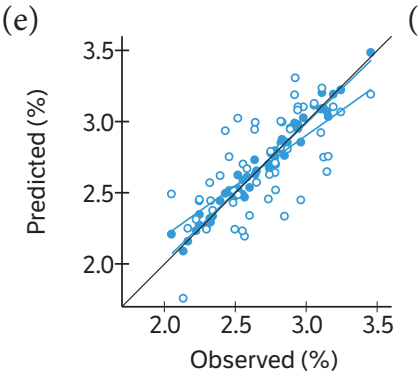

- Cal o Val

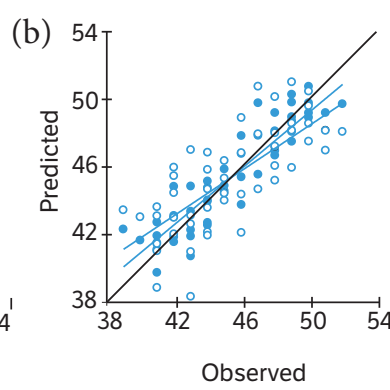

(f)

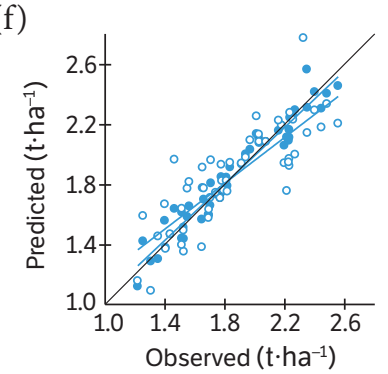

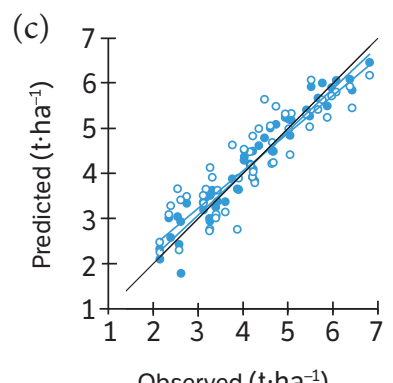

Observed $\left(\mathrm{t} \cdot \mathrm{ha}^{-1}\right)$

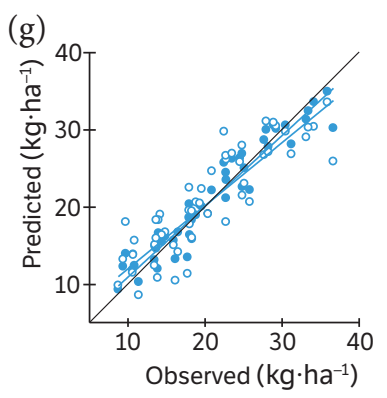

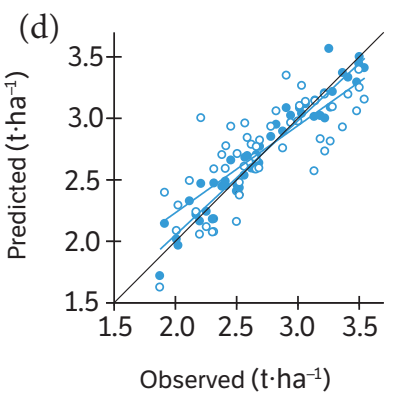

(h)

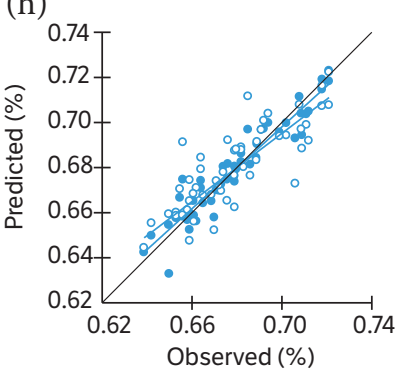

Figure 3. Relationships between the observed and predicted (a) biomass dry weight, (b) biomass fresh weight, (c) nitrogen concentration, (d) nitrogen uptake, (e) SPAD value, (f) pod yield, (g) seed yield, and (h) shelling percentage of 2 peanut cultivars at BBCH 35 for the calibration (cal) and validation (val) datasets using a partial least square model. Statistical information is given in Table 7.

robust when using PLSR models than with the previously assayed normalized difference spectral indices. This is shown by the improvement of the coefficients of determination in Table 7. These results agree with those of Sharabian et al. (2014), who found that strong relationships existed between predicted and observed values for a validation data set of grain yield $\left(\mathrm{R}^{2}=0.87, \mathrm{RMSE}=301\right)$ and SPAD values $\left(\mathrm{R}^{2}=0.84, \mathrm{RMSE}=1.94\right)$. Elsayed et al. $(2015 \mathrm{a})$ reported that
PLSR models could improve the assessment of pod yield in peanut cultivars compared to the spectral reflectance indices collected from other studies. Li et al. (2014) found that PLSR is a potentially useful approach to derive the crop canopy nitrogen concentration of winter wheat across growth stages when compared to spectral indices; the average $\mathrm{R}^{2}$ value for the PLSR model increased to 76.8 and $75.5 \%$ in the calibration and validation data sets, respectively. 

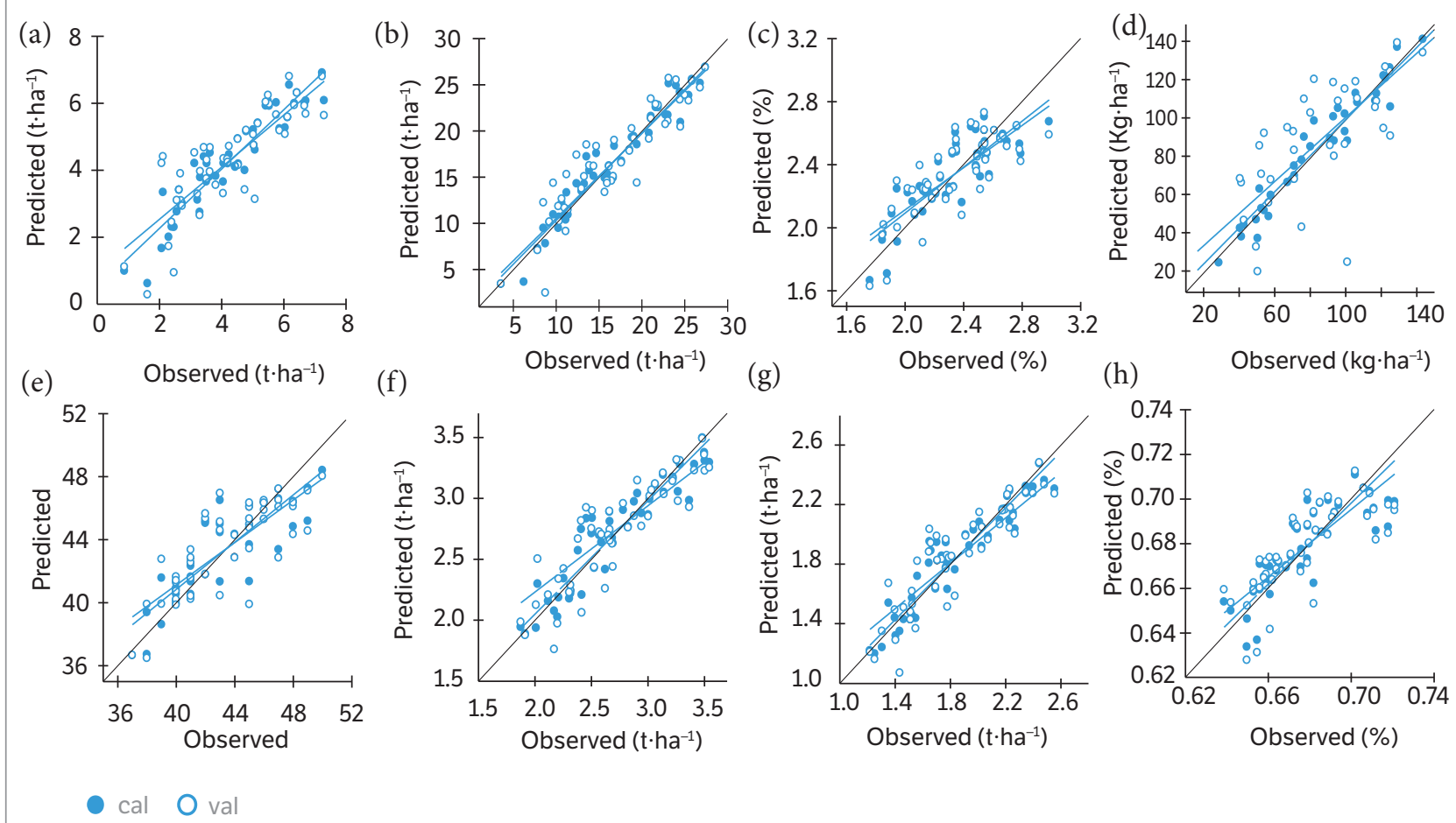

Figure 4. Relationships between the observed and predicted (a) biomass dry weight, (b) biomass fresh weight, (c) nitrogen concentration, (d) nitrogen uptake, (e) SPAD value, (f) pod yield, (g) seed yield, and (h) shelling percentage of 2 peanut cultivars at BBCH 85 for the calibration (cal) and validation (val) datasets using a partial least square model. Statistical information is given in Table 7.

\section{CONCLUSION}

From the above results, it could be concluded that inoculation of peanut plants with Bradyrhizobium and plant growth-promoting rhizobacteria enhanced the biomass, nitrogen status, and final yield of peanut cultivars under different levels of nitrogen application compared with non-inoculated plants. The models developed from the normalized difference spectral indices and PLSR analyses reliably assessed the measured plant parameters for 2 peanut cultivars. The calibration of PLSR models of reflectance measurements potentially improves measurements of non-invasive parameters of peanut crops compared with normalized difference spectral indices analysis.

\section{ACKNOWLEDGEMENTS}

The authors would like to extend their sincere appreciation to the Deanship of Scientific Research at the King Saud University for funding this Research Group No. (RG-1435-032).

\section{REFERENCES}

Association of Official Analytical Chemists (1980). Official methods of analysis. 13. ed. Washington: AOAC.

Atlas, R. M. (1995). Handbook of media for environmental microbiology. Boca Raton: CRC Press.

Badawi, F., Biomy, A. and Desoky, A. (2011). Peanut plant growth and yield as influenced by co-inoculation with Bradyrhizobium and some rhizo-microorganisms under sandy loam soil conditions. Annals of Agricultural Sciences, 56, 17-25. http://dx.doi.org/10.1016/j. aoas.2011.05.005.

Bai, Y., Souleimanov, A. and Smith, D. I. (2002). An inducible activator produced by Serratia proteamaculans strain and its soybean growth-promoting activity under greenhouse conditions. Journal 
of Experimental Botany, 53, 1495-1502. http://dx.doi.org/10.1093/ jexbot/53.373.1495.

Barnes, E. M., Clarke, T. R., Richards, S. E., Colaizzi, P. D., Haberland, J. and Kostrzewski, M. (2000). Coincident detection of crop water stress, nitrogen status and canopy density using ground-based multispectral data. Proceedings of the $5^{\text {th }}$ International Conference on Precision Agriculture, Bloomington, MN, USA.

Barik, A. K., Mukherjee, A. K. and Mendal, B. K. (1998). Growth and yield of Sorghum (Sorghum bicolor L.) and groundnut (Arachis hypogaea L.) grown as sole and intercrops under different regimes. Indian Journal of Agronomy, 43, 27-32.

Bonfil, D. J., Karnieli, A., Raz, M., Mufradi, I., Asido, S., Egozi, H., Hoffman, A. and Schmilovitch, Z. (2005). Rapid assessing of water and nitrogen status in wheat flag leaves. Journal of Food, Agriculture \& Environment, 3, 148-153.

El-Hendawy, S., Al-Suhaibani, N., Salem, A., Ur Rehman, S. and Schmidhalter, U. (2015). Spectral reflectance indices as a rapid nondestructive phenotyping tool for estimating different morphophysiological traits of contrasting spring wheat germplasms under arid conditions. Turkish Journal of Agriculture and Forestry, 39, 572-587. http://dx.doi.org/10.3906/tar-1406-164.

Elsayed, S., Elhoweity, M. and Schmidhalter, U. (2015a). Normalized difference spectral indices and partial least squares regression to assess the yield and yield components of peanut. Australian Journal of Crop Science, 9, 976-986.

Elsayed, S., Mistele, B. and Schmidhalter, U. (2011). Can changes in leaf water potential be assessed spectrally? Functional Plant Biology, 38, 523-533. http://dx.doi.org/10.1071/FP11021.

Elsayed, S., Rischbeck, P. and Schmidhalter, U. (2015b). Comparing the performance of active and passive reflectance sensors to assess the normalized relative canopy temperature and grain yield of drought-stressed barley cultivars. Field Crops Research, 177, 148-160. http://dx.doi.org/10.1016/j.fcr.2015.03.010.

Erdle, K., Mistele, B. and Schmidhalter, U. (2011). Comparison of active and passive spectral sensors in discriminating biomass parameters and nitrogen status in wheat cultivars. Field Crops Research, 124, 74-84. http://dx.doi.org/10.1016/j.fcr.2011.06.007.

Erdle, K., Mistele, B. and Schmidhalter, U. (2013). Spectral assessments of phenotypic differences in spike development during grain filling affected by varying $\mathrm{N}$ supply in wheat. Journal of Plant Nutrition and Soil Science, 176, 952-963. http://dx.doi. org/10.1002/jpln.201300247.
Erisman, J. W., van Grinsven, H., Leip, A., Mosier, A. and Bleeker, A. (2010). Nitrogen and biofuels: an overview of the current state of knowledge. Nutrient Cycling in Agroecosystems, 86, 211-223. http://dx.doi.org/10.1007/s10705-009-9285-4.

Fu, Y., Yang, G., Wang, J., Song, X. and Feng, H. (2014). Winter wheat biomass estimation based on spectral indices, band depth analysis and partial least squares regression using hyperspectral measurements. Computers and Electronics in Agriculture, 100, 51-59. http://dx.doi.org/10.1016/j.compag.2013.10.010.

Furbank, R. T. and Tester, M. (2011). Phenomics - technologies to relieve the phenotyping bottleneck. Trends in Plant Science, 16, 635-644. http://dx.doi.org/10.1016/j.tplants.2011.09.005.

Gutiérrez, M., Reynolds, M. P., Raun, W. R., Stone, M. L. and Klatt, A. R. (2010). Spectral water indices for assessing yield in elite bread wheat genotypes in well irrigated, water stressed, and high temperature conditions. Crop Science, 50, 197-214. http://dx.doi. org/10.2135/cropsci2009.07.0381.

Li, F., Mistele, B., Hu, Y., Chen, X. and Schmidhalter, U. (2014). Reflectance estimation of canopy nitrogen content in winter wheat using optimized hyperspectral spectral indices and partial least squares regression. European Journal of Agronomy, 52, 198-209. http://dx.doi.org/10.1016/j.eja.2013.09.006.

Mekhemar, G. A. A., Shaaban, M., Ragab, A. A. and Biomy, A. M. M. (2005). Response of faba bean to inoculation with Rhizobium leguminosarum bv. Viceae and plant growth promoting rhizobacteria under newly reclaimed soils. Journal of Applied Sciences, 20, 126-144.

Mistele, B. and Schmidhalter, U. (2008). Estimating the nitrogen nutrition index using spectral canopy reflectance measurements. European Journal of Agronomy, 29, 184-190. http://dx.doi. org/10.1016/j.eja.2008.05.007.

Mistele, B. and Schmidhalter, U. (2010). Tractor-based quadrilateral spectral reflectance measurements to detect biomass and total aerial nitrogen in winter wheat. Agronomy Journal, 102, 499-506. http://dx.doi.org/10.2134/agronj2009.0282.

R Foundation for Statistical Computing (2013). R-3.0.2 for Windows (32/64 bit); [accessed 2017 Jan 4]. https://cran.r-project.org/bin/ windows/base/old/3.0.2/

Rischbeck, P., Baresel, J. P., Elsayed, S., Mistele, B. and Schmidhalter, U. (2014). Development of a diurnal dehydration index for spring barley phenotyping. Functional Plant Biology, 41, 1249-1260. http:// dx.doi.org/10.1071/FP14069. 
Robson, A., Wright, G. and Phinn, S. (2004). Assessment of peanut crop maturity and yield forecasting with quick bird multispectral satellite imagery. Spatial Science Queensland, 4, 35-37.

Schmidhalter, U., Jungert, S., Bredemeier, C., Gutser, R., Manhart, R., Mistele, B. and Gerl, G. (2003). Field-scale validation of a tractor based multispectral crop scanner to determine biomass and nitrogen uptake of winter wheat. Precision Agriculture, 615-619.

Sharabian, R. V., Noguchi, N. and Ishi, K. (2014). Significant wavelengths for prediction of winter wheat growth status and grain yield using multivariate analysis. Engineering in Agriculture, Environment and Food, 7, 14-21. http://dx.doi.org/10.1016/j. eaef.2013.12.003.

Tilak, K. V. B. R., Ranganayaki, N., Pal, K. K., De, R., Saxena, A. K., Nautiyal, C. S., Mittal, S., Tripathi, A. K. and Tohri, B. N. (2005). Diversity of plant growth and soil health supporting bacteria. Current Science, 89, 136-150.

Townsend, P. A., Foster, J. R., Chastain, R. A. and Currie, W. S. (2003). Application of imaging spectroscopy to mapping canopy nitrogen in the forests of the central Appalachian Mountains using Hyperion and AVIRIS. IEEE Transactions on Geoscience and Remote Sensing, 41, 1347-1354. http://dx.doi.org/10.1109/TGRS.2003.813205.
Verma, J. P., Yadav, J., Tiwari, K. N. and Singh, V. (2010). Impact of plant growth promoting rhizobacteria on crop production. International Journal of Agricultural Research, 5, 954-983. http:// dx.doi.org/10.3923/ijar.2010.954.983.

Vincent, J. M. (1970). A manual for the practical study of the root nodule bacteria. IBP, Hand Book No. 15. Oxford: Blackwell Publishers.

Walter, A., Studer, B. and Kölliker, R. (2012). Advanced phenotyping offers opportunities for improved breeding of forage and turf species. Annals of Botany, 110, 1271-1279. http://dx.doi.org/10.1093/ $\mathrm{aob} / \mathrm{mcs} 026$.

Weber, V. S., Araus, J. L., Cairns, J. E., Sanchez, C., Melchinger, A. E. and Orsini, E. (2012). Prediction of grain yield using reflectance spectra of canopy and leaves in maize plants grown under different water regimes. Field Crops Research, 128, 82-90. http://dx.doi. org/10.1016/j.fcr.2011.12.016.

Winterhalter, L., Mistele, B. and Schmidhalter, U. (2012). Assessing the vertical footprint of reflectance measurements to characterize nitrogen uptake and biomass distribution in maize canopies. Field Crops Research, 129, 14-20. http://dx.doi.org/10.1016/j. fcr.2012.01.007. 